\title{
LETRAS EM REVISTAS MÁRIO DE ANDRADE, MINAS E OS MINEIROS
}

\author{
Murílo Rubião
}

Toda época tem os seus revolucionários. Os que não se conformam com os erros do seu tempo, com a mediocridade dos que não conseguem desprender-se dos modelos velhos, sentindo a incapacidade para criar novos.

Assim aconteceu com Mário de Andrade. Surgiu num periodo em que a nossa literatura estava estagnada, amordaçada pelas caturrices dos gramáticos, pelo formalismo de poetas que da poesia conheciam apenas o metro e a rima (quando conheciam!). Numa época de incultura geral.

Enfiou-se longo na falange dos modernistas. Foi atacado e injuriado por todo o mundo. Cousa, aliás, que sempre acontece com aqueles que têm o desassombro de defender uma idéia nova. A propósito desses ataques por ele sofridos, nos conta, que ao ver a primeira crítica elogiosa do seu livro 
"Há uma gota de sangue em cada poema", foi tanta a sua alegria, que saiu para a rua sem saber o fazer, sem saber aonde ir... Depois o atacaram tanto, que ele não mais se importou com os críticos literários...

Infelizmente, como já dissemos, o modernismo, no Brasil, coincidiu com uma época de incultura geral. E desse movimento que tanto bem fez à nossa literatura, poucos nomes ficaram ao lado dêsses grandes espíritos que são Mário de Andrade, Manuel Bandeira e Carlos Drummond de Andrade.

Aproveitando a estada em Belo Horizonte, do primeiro desses escritores citados, onde fez duas notáveis conferências, solicitamos dele uma entrevista.

Foi uma conversa longa, onde pudemos admirar no escritor que já era grande demais para nós, as qualidades de homem que ainda não conhecíamos. Ao par de sua prosa brilhante e da sua cultura, geral e imensa, a sua grande bondade no falar dos homens e a sua compreensão desmedida, em falando das cousas da vida.

Encantados com a sua prosa simples e deslumbrante ao mesmo tempo, e a sua acolhedora bondade, principalmente no tratar com os moços, enfileiramo-nos no grupo de rapazes que diariamente conversavam com o Mário de Andrade.

E tanta cousa de interessante dele ouvimos, que desistimos da primitiva entrevista, para fixar aqui apenas um apanhado das opiniões e impressões, que nos foi dado ouvir desse magnífico autor que já escreveu sobre tudo e em tudo que escreveu, foi mestre. Crítico literário, musical, romancista, poeta, etc. Sempre original, sempre profundo. E nele há tanta honestidade e consciência da arte, que sendo um dos maiores conhecedores da música na América do Sul, nunca deu aula a alunos medíocres, embora altamente remunerado. E mesmo os alunos que se revelavam virtuoses em formação, eram desprezados, para dar lugar aos que podiam criar alguma cousa.

Mário de Andrade tem um carinho especial e anti- go por Minas e pelos seus intelectuais. É a terceira vez que vem aqui. Na primeira, em $1917^{*}$, visitou vários lugares, entre os quais Belo Horizonte, Diamantina e Ouro Preto. Sendo que esta última, ele conhecia de cor, pelas leituras constantes que fizera antes de visitá-la.

Ele nos contou muita cousa dessa viagem. Antes de iniciá-la, fez um estudo completo sobre o nosso Estado. Conhecia toda a sua história, tudo que lhe pudesse interessar na excursão que empreendia com o coração e o espírito. E também porque, diz ele, "sempre me impressionou a história de Minas, porque nela encontramos as diretivas mestras da nossa formação moral e política".

Nessa viagem, indo a Diamantina, ficou conhecendo Alphonsus de Guimaraens, que ele considera um dos maiores sonetistas do Brasil. "O qual - diz ele desoladamente — não recebeu de sua época a consagração que merecia. Os críticos receberam os seus versos como os de um poeta qualquer".

Falando sobre os autores mineiros, o poeta de "Noturno de Belo Horizonte", que os considera muito individualistas, disse: "Exemplificando o que foi dito por mim, vemos em Carlos Drummond, Emilo Moura e Murilo Mendes (que Mário situa entre os maiores poetas modernos do Brasil) tres mundos inteiramente diferentes". E continuou: "Não há unidade na literatura mineira. E nem sei se haveria necessidade dela. Mas existe aqui uma grande tradição de cultura, a que têm obedecido os literatos de Minas, que, além de serem demasiado sérios e honestos, nunca cultivaram o cabotinismo de certos literatos nossos".

Mário de Andrade gosta mais da poesia do que do romance mineiro. No entanto, acha que este último é bom. E considera, entre os modernos, Ciro dos Anjos ("menos machadeano do que se diz") autor de um romance definitivo e quase perfeito. Guilhermino é, na opinião dele, outro nome que se está avultando no nosso romance. "Por João Alphonsus, o admirável autor de "Galinha cega", tenho uma admiração enorme, vinda de muito longe." 


\section{ANOS DE MÁRIO}

Muita cousa ainda ouvimos de Mário de Andrade. Mas seria impossível, no limitado espaço deste grifo, contar tudo que dele nos foi dado ouvir. Assim, deixamos aqui apenas algumas impressões sobre Minas e seus literatos desse grande escritor que, com a sua grande cultura e não menor bondade, conquistou inteiramente a mocidade mineira, há muito conquistada pelo brilho e pelo valor da sua fulgurante obra literária.

* Nota da redaçāo: A primeira viagem de Mário de Andrade a Minas foi em 1919 e nāo em 1917.

Publicado em TENTATIVA No 8, p. 30, Belo Horizonte, novembro 39. Acervo Murilo Rubião. CEL - UFMG 